\title{
SIX SIGMA METHODOLOGY - TOOL FOR IMPROVING THE CAPABILITY OF THE PRODUCTION PROCESS
}

\author{
Elena Papazoska ${ }^{1}$, Gligorče Vrtanoski ${ }^{2}$ \\ ${ }^{1}$ MSc Student at the Faculty of Mechanical Engineering, "Ss. Cyril and Methodius" University in Skopje, \\ P.O. box 464, MK-1001, Skopje, Republic of North Macedonia \\ ${ }^{2}$ Faculty of Mechanical Engineering, "Ss. Cyril and Methodius" University in Skopje, \\ P.O. box 464, MK-1001, Skopje, Republic of North Macedonia \\ gligorche.vrtanoski@mf.edu.mk
}

\begin{abstract}
A b s t r a c t: Modern industrial production companies on a global scale over the past decade have been facing sectoral challenges in terms of competitiveness, reducing production costs and increasing the quality of products and services. This challenge is especially focused on investing in scientific, systematic models for development, monitoring and maintenance of production facilities, but always the main emphasis is on the sustainability of quality in the conditions of rapid expansion of the global market and automation of the industry. Topic in this paper is Six Sigma Methodology. Six Sigma is statistical methodology for normalizing process and a methodology that is data-driven and customer focused, highly disciplined process that help develop and deliver near perfect product and services. Results of research in this paper, the practical example, clearly show the importance of the sistematic analysis and usage of the Six Sigma methodology in the productive processes with DMAIC method for stabilization, improvement and reduction of standard deviation.
\end{abstract}

Key words: 6 sigma; black belt; depanelization; printed circued board (PCB); DMAIC

\section{МЕТОДОЛОГИЈАТА ШЕСТ СИГМА - АЛАТКА ЗА ПОДОБРУВАЊЕ НА СПОСОБНОСТА НА ПРОЦЕСОТ НА ПРОИЗВОДСТВОТО}

\begin{abstract}
А п с т р а к т: Современите компании за индустриско производство на глобално ниво во последната деценија се соочуваат со сериозни предизвици од аспект на конкурентност, редуцирање на трошоците за производството и зголемување на квалитетот на производите и услугите. Овој предизвик е посебно насочен кон инвестирање во научни, систематски модели за развој, следење и одржување на производните капацитети, а секогаш главен акцент е ставен на одржливоста на квалитетот во условите на брзата експанзија на глобалниот пазар и автоматизацијата на индустријата. Во трудот е претставена методологијата шест сигма. Шест сигма е статистичка методологија за нормализирање на процесот, а наедно и методологија ориентирана кон податоци и клиенти за високо дисциплинирани процеси кои овозможуваат постигнување услуги и производи кои се стремат кон совршенство. Резултатите од истражувањата во овој труд, поточно квантитативното подобрување добиено со практичниот пример, ја посочуваат важноста на систематското анализирање и на примената на методологијата 6 сигма во производствените процеси преку методот DMAIC за стабилизирање, подобрување и намалување на стандардната девијација.
\end{abstract}

Клучни зборови: 6 сигма; црн појас; депанелизирање; печатено електронско коло (ПЕК); методологија DMAIC

\section{INTRODUCTION}

The research carried out in this paper relates to the 6 Sigma methodology and its practical application in the production process. The main goal is to demonstrate the importance and the benefit of improving production processes through the application of the 6 Sigma methodology.

The implementation of the 6 Sigma methodology will be explained by the five phases of a real 
practical example, and in order to achieve a reduction in the number of defective outputs from it.

In the first phase, define phase, explains the importance of setting a measurable target for the project. Proportionately predicts improvement and a clear direction for the movement of the team that will prepare the project, its selection and the special role of all the members. It is also analyzed according to which parameters it is chosen whether the project should be developed using the 6 Sigma methodology.

In the second phase, measure phase, the diagrams WPI-input-process-output and the basic process flow diagram are presented [5].

Initially, the validation of the measuring tool that the team selected for use in measuring the exit from the process, as well as all the conditions that need to be fulfilled, is presented. Their quantitative values are displayed and analyzed in the Minitab software package [2] which gives the acceptance of the measurement system. The parameters that should be measured as a way out of the process are also defined. At this stage, tests for stability, normality and ability of the process are shown.

In the third phase, the analyze phase provides an overview of the cause-effect diagram used to identify the potential causes of the defect to be eliminated. In particular, the way in which the causes, i.e. the reasons that can be controlled and the reasons that can not be controlled, are shared. To eliminate potential causes, the "5 Why" tool (the tool that continuously asks "Why" until the problem is reached) and by analyzing the other reasons with the tests of the 6 Sigma methodology and the Design of Experiment (DE), and hypothesis testing [5].

The next phase of the 6 Sigma methodology is the improve phase shown through the performed setting of the improvement parameters and the way how to validate the selected solution.

Control is the last phase that represents the way how to control the improved process and how to set up solid controls for the solution to stay set for the process for which it has been defined.

\section{THEORETICAL CONCEPT OF 6 SIGMA METHODOLOGY}

Interesting fact is that despite the great interest, available literature, research, international conferences, workshops and seminars, each company has its own specific method and method of applying the 6 Sigma methodology.

Six Sigma methodology refers to the orientation towards finding and eliminating the causes of variation in the processes. Also 6 Sigma develops an alternative that will lead to a reduction in variation. Six Sigma seen from an organizational level is a quality management structure that focuses on continual improvement of four key areas [7,8]:

$>$ understanding and managing the requirements of customers,

$>$ streamlining the key processes to the desired results,

$>$ using a large amount of data to analyze in order to minimize variation in key processes,

$>$ fast and constant improvements in business process.

Six Sigma as a quality management tool also includes metrics and methodology. That largely contributed to a marked success is the fact that the result of the improvement can be quantitatively expressed in number of defects and savings in money $[7,8]$.

When implementing the 6 Sigma model there are certain conditions that need attention and fulfillment increases the chances for success of the 6 Sigma initiative, which are $[10,11]$ :

$>$ support from top management.

$>$ organizational structure.

$>$ application of advanced statistical techniques,

$>$ developing ways to reward 6 Sigma team.

The goal of 6 Sigma is to generate an improvement in the performance of an organization that aims to determine based on the requirements of its customers at which level of Sigma is appropriate the operation of the process. Sometimes a 6 Sigma level with 3.4 DPMOs is not a target for all processes due to the financial aspect of the bet $[12,13]$.

Six Sigma methodology uses two different models [3]:

$>$ basic model for project - based projects in the functioning processes (DMAIC), shown in Figure 1, and

$>$ basic model used to design new processes and create new products or services (DMADV), shown in Figure 2. 


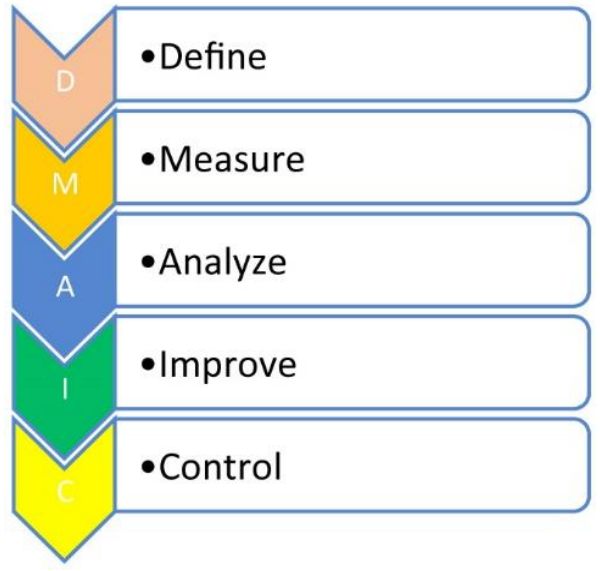

Fig. 1. DMAIC basic model



Fig. 2. DMADV basic model

\section{APPLYING 6 SIGMA METHODOLOGY IN REAL PRODUCTION CASE}

The selected practical project using the 6 Sigma methodology shows the main benefit of applying the 6 Sigma through the results obtained from the real case. Using the Minitab software package allows you to analyze and display the results obtained from the practical example.

\subsection{Define phase}

The 6 Sigma project that has been developed refers to improving the process of depanelization. The process of depaneling of the printed circuit board is one of the main reasons for the quality problems and returned products by the client. Depanelization is a production process that is placed in the central position during production, more precisely, any defect in this process means spent time and money from all preceding processes.
Printed circuit board (PCB) arrives in panel and is depanelized on the milling machine.

Depaneling operation is done of combination of manual and machine work in the next steps:

$>$ Operator place PCB in the machine (Figure 3).

$>$ Machine using rotation movement of the blades perform the depanelization process.

$>$ Operator take the PCBs out and throw not needed borders as a waste material.

$>$ Operator visualy checks depanelization quality.

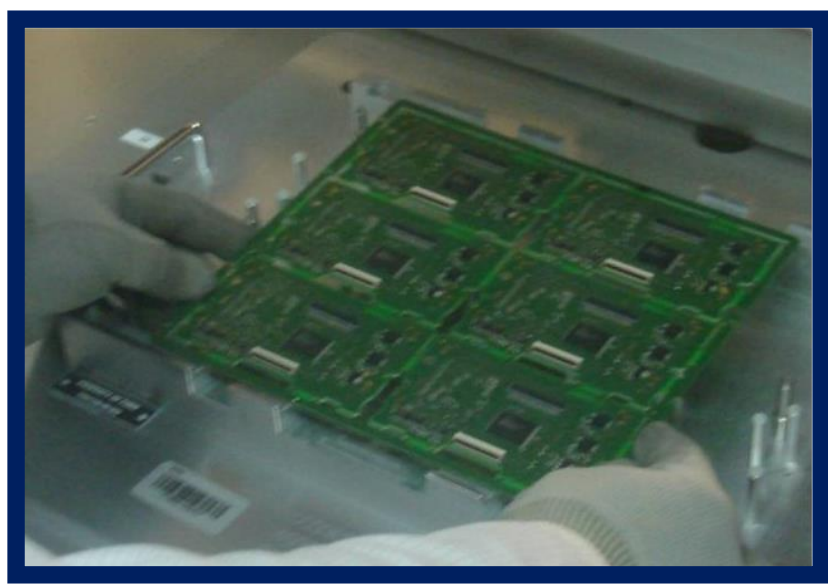

Fig. 3. Printed circuit board (PCB) in panel

Milling machine produces defective products (Figure 4) which can not be completely detected in the production scope and as such are sent to the client.

\subsubsection{Problem statement}

Inside process of depanelization we can notice several risks:

Improper depanelization (demaged PCB) of the printed circuit boards.

The cutting quality is checked visually after the depanelization is performed, which does not guarantee the assurance that only "good" pieces will be sent to the client.

\subsubsection{Project objective}

The goal of the project is measurable of the quality of the process expressed through the benefit of the business $Y_{B}$ and product quality expressed through customer satisfaction from the product $Y_{c}$. This can be explained as: eliminating the defects for the production unit and eliminating products that are returned from the client. 

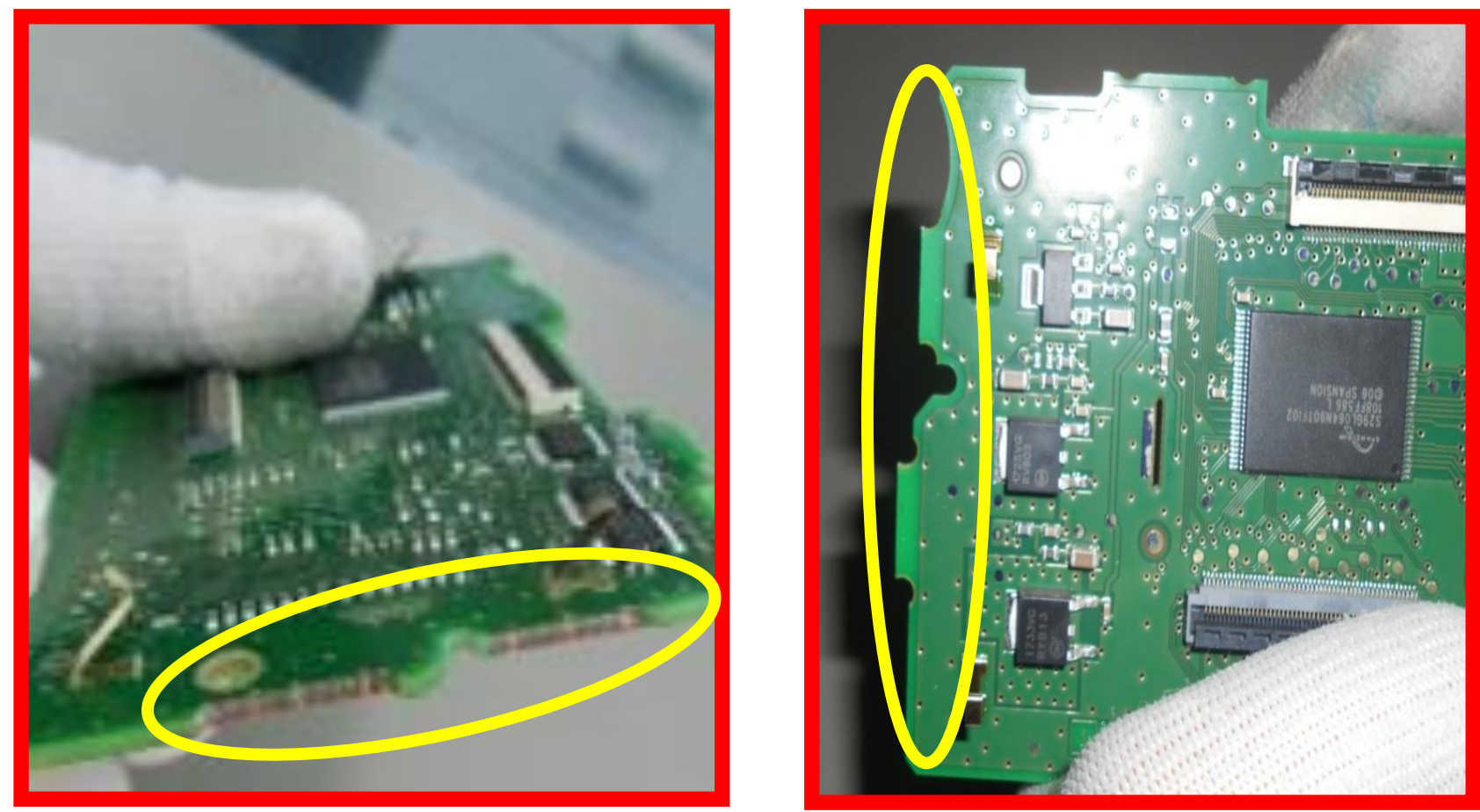

Fig. 4. Defects of depanelization process

\subsubsection{Selection and problem elimination}

When selecting is a priority for improvement, Pareto diagrams are used that show the need to prioritize the elimination of an appropriate problem.

Data for returned products from customers, defects in the production process, utilization / inexperience of production facilities, delays and others are used as input data for analysis. However, the most important data in the analysis are the products returned by customers.

The Pareto diagram given in Figure 5 shows the total number of monthly returned products from customers, of which $50 \%$ belong to one product from the entire range of products (Figure 6).

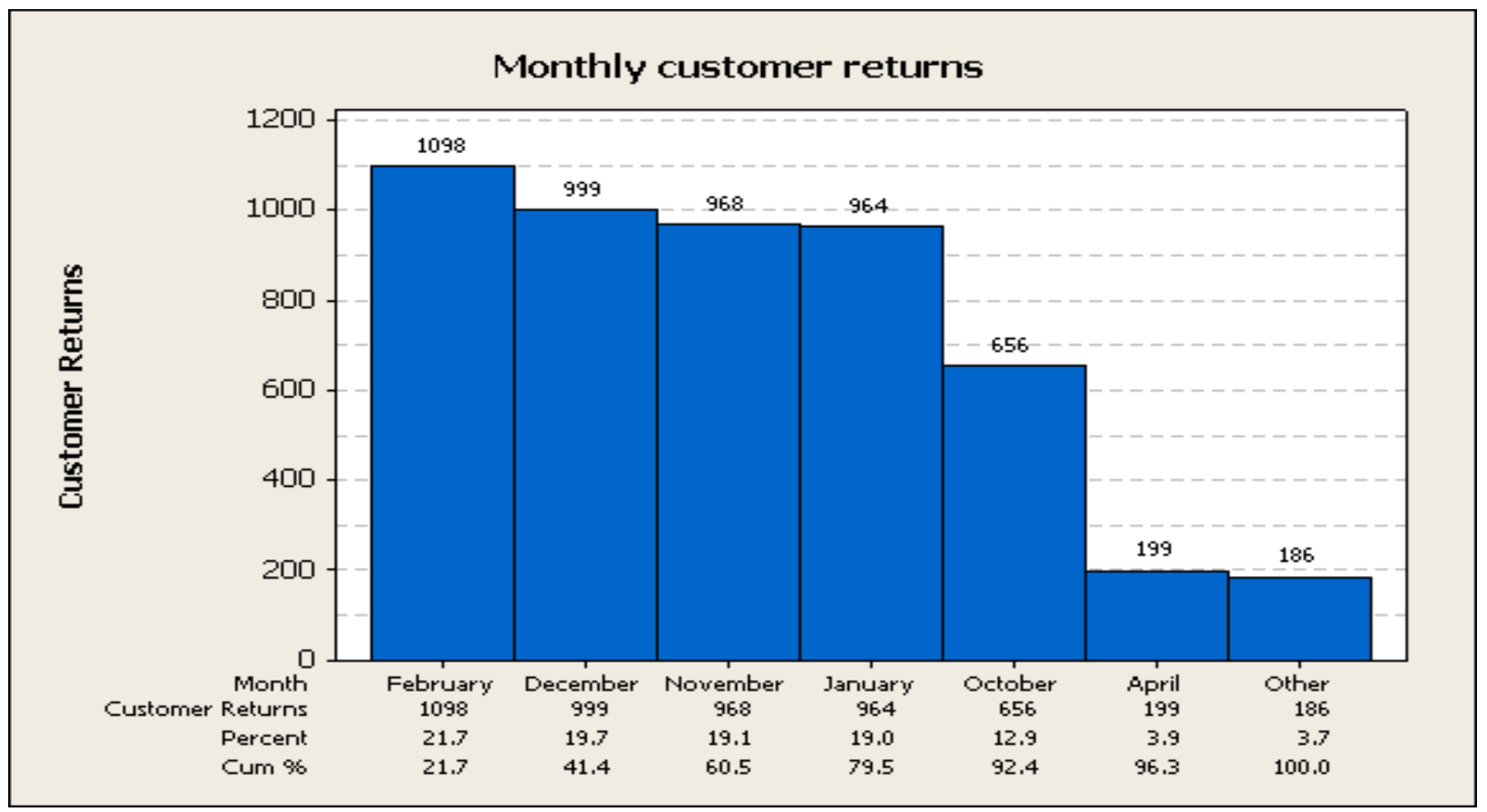

Fig. 5. Number of returned printed circuit boards from customeres 


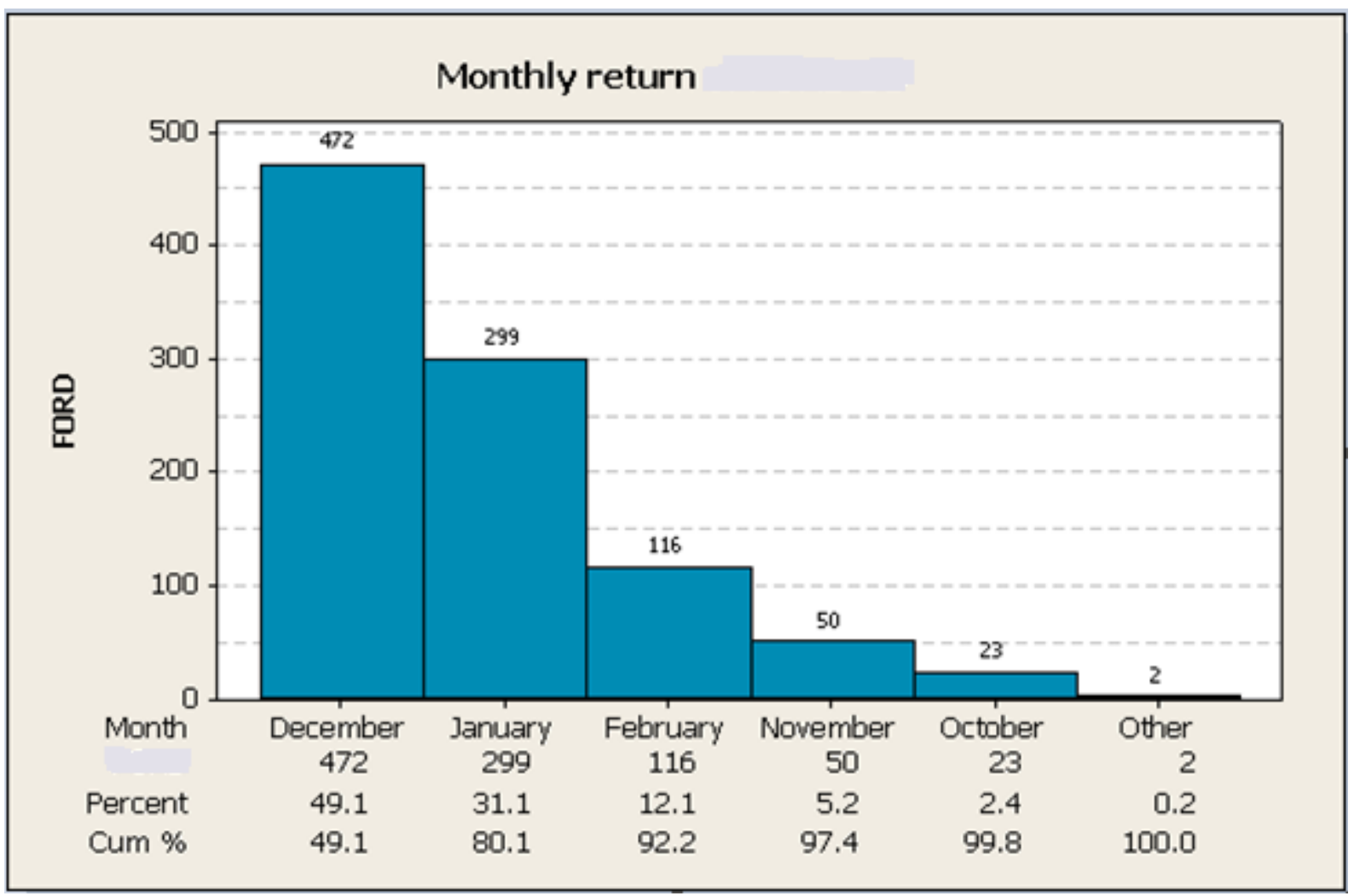

Fig. 6. Number of returned printed circuit boards of the analyzed product

With deeper analysis we can see which internal process is giving most defective non-wanted type of products which are main reason for customer returns. This is shown on the Pareto diagram on Figure 7, where we can observe number of montly customer returns due to depanelization process of the selected product.

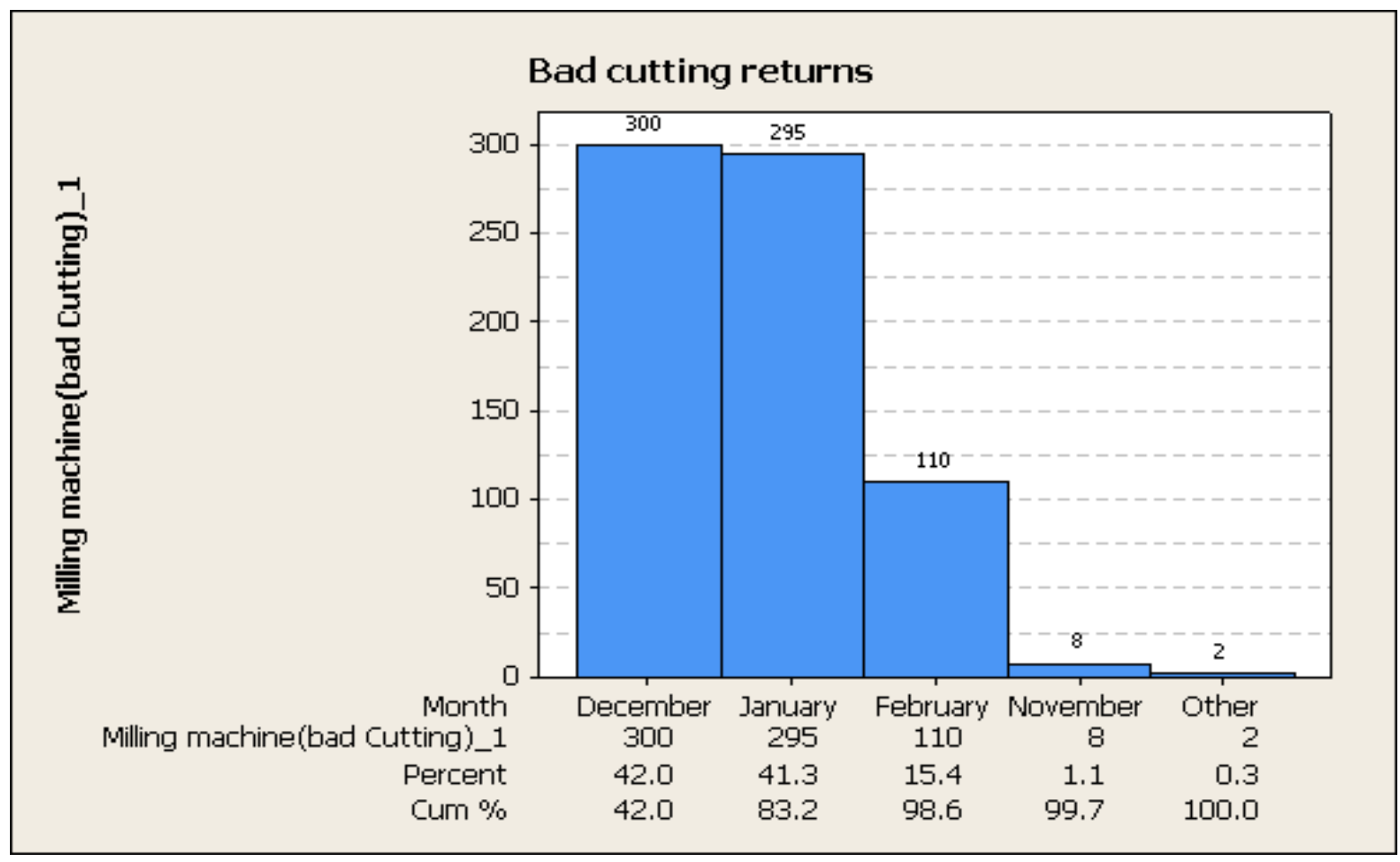

Fig. 7. Number of returned PCB of the analyzed product per months 
It is obvious that by eliminating deviation in the process of depanelization, improvement is made. This will reduce the number of returned products by the client by $60 \%$, which would increase client satisfaction, confidence and the success for further cooperation.

\subsection{Measure phase}

\subsubsection{Diagrams for clarifying the process}

Measure phase is closely connected with analyze phase. This phase contains several crucial elements, such as selecting a proper correct measurement system (MS, gage), a method of measurement, trained personnel to perform the measurement, and selecting an appropriate measurable product that will clearly reflect the problem. Later this measurable will be used through the phase analysis and phase control. That's why the team's versatility and their specific knowledge of production play a key role here.

In the measure phase, it is decided what will be measured and the validation of the measuring system is carried out.

At this stage, the goal to be achieved by the client $Y_{C l}$ and the business $Y_{B I}$ is set.

The improvement expected to be achieved by the team is the reduction of the products returned by the client and the reduction of the production defects. They are:

$>Y_{C l}=$ reduce customer return for the milling defects due to not proper cutting ( $x$-axis and $y$-axis dimensions) for $100 \%$.

> $Y_{B I}=$ reduce internal scrap for the milling defects due to not proper cutting ( $x$-axis and $y$ axis dimensions) for $90 \%$.

In addition to defining the goal of the business and the client, the goal to be achieved from the corresponding process is also defined $Y_{P I}$ :

$>Y_{P I}=$ distance between two dots of the printed circuit board (dimensions of $x$-axis and $y$-axis).

The Input-Process-Output diagram shown in Figure 8 provides the input attributes, the main process and the output attributes of the system being analyzed.

The 6 Sigma methodology always provides more reliable results if the variables of the automatic processes are analyzed, rather than from the manual ones. This is because automated processes are subject to greater variation.

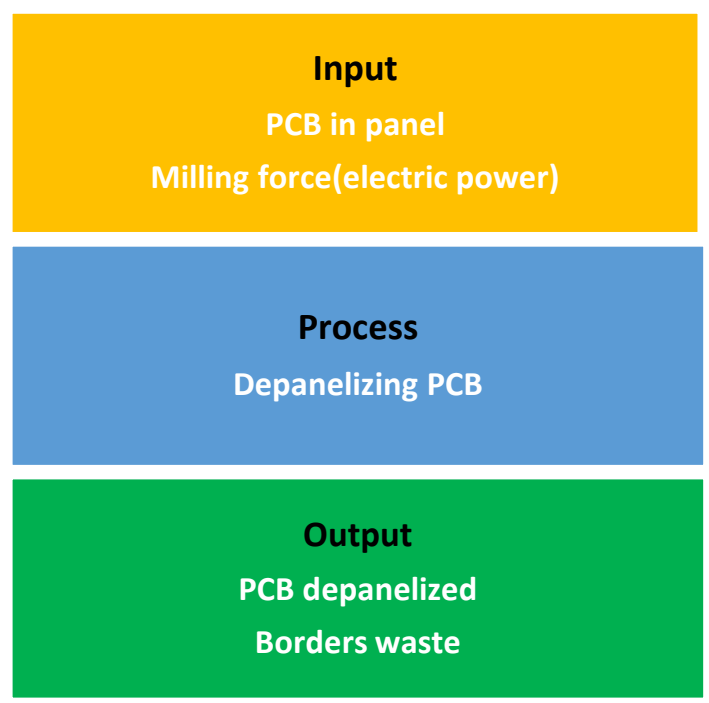

Fig. 8. Input-Process-Output diagram

The initial flow of the process is presented in the diagram shown in Figure 9 which purpose is to have a visual display of the process.

In this process there is only one automatic operation to which the improvement is expected later.

\subsubsection{Determinating and validation of the measure system}

The next step is to determine the measurement system that will be used in the phase of measuring, improving and validating the solution.

First, Gage R\&R is being developed to implement validation of the measurement system. In this case, ten printed electronic circuits (PCBs) and two operators (employees who have previous experience with manipulating the measuring machine).

The graphical display for validating the measurement system given in Figure 10 clearly shows that there is an insignificant variation between the operator one (1) and the operator two (2) in the execution of the measurement process, but also that there is an insignificant variation between the printed circuit boards (PCB) in all four measurements performed.

In the part of the numerical display of the validation of the measurement system, the number of categories is 30 which is greater than $5(30>5)$. This proves that the selected measurement system is suitable for measurement.

The most complicated point of the printed circuit board (PCB) or precisely the distance between the two closest points and the same is used to measure it. 


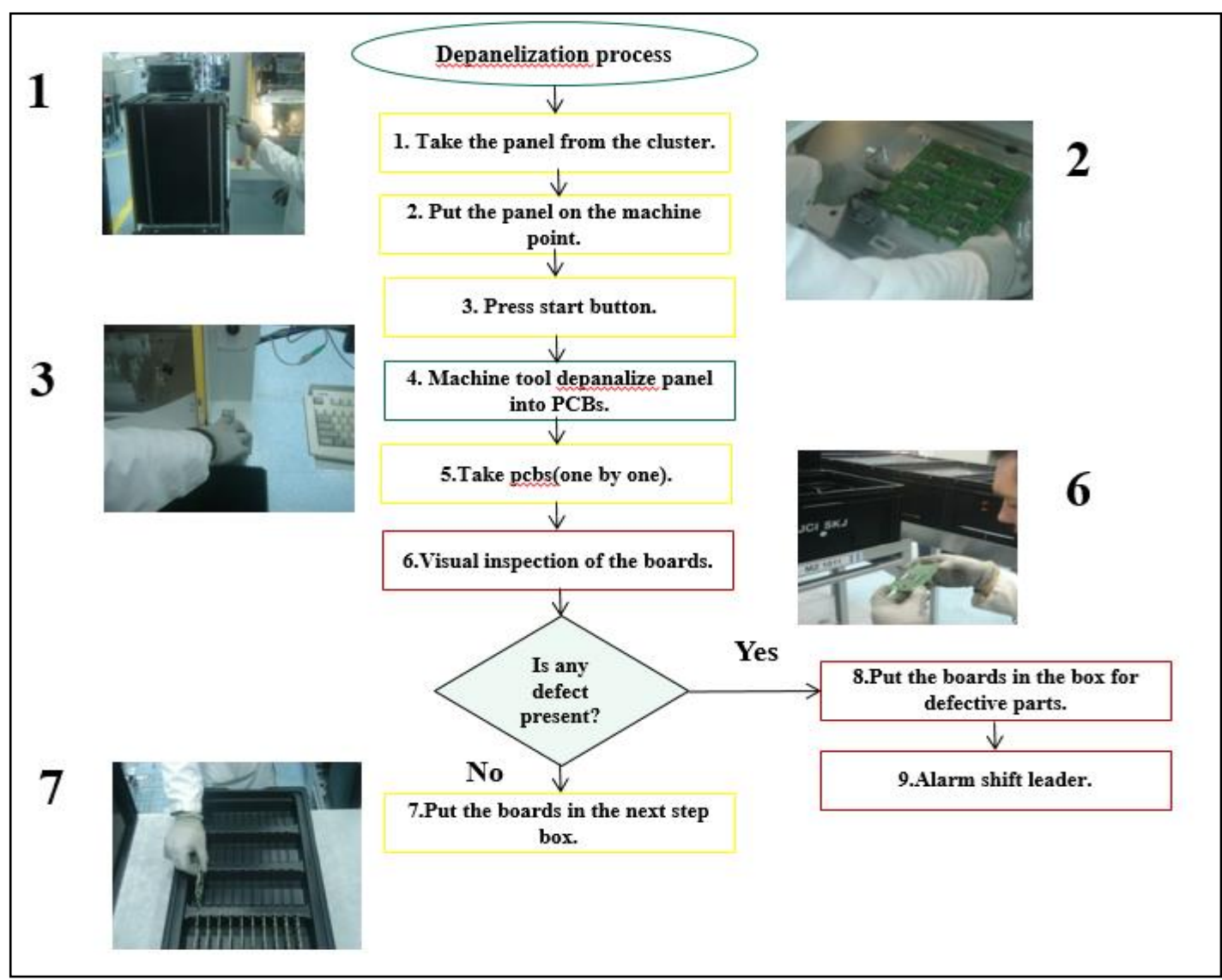

Fig. 9. Process flow diagram

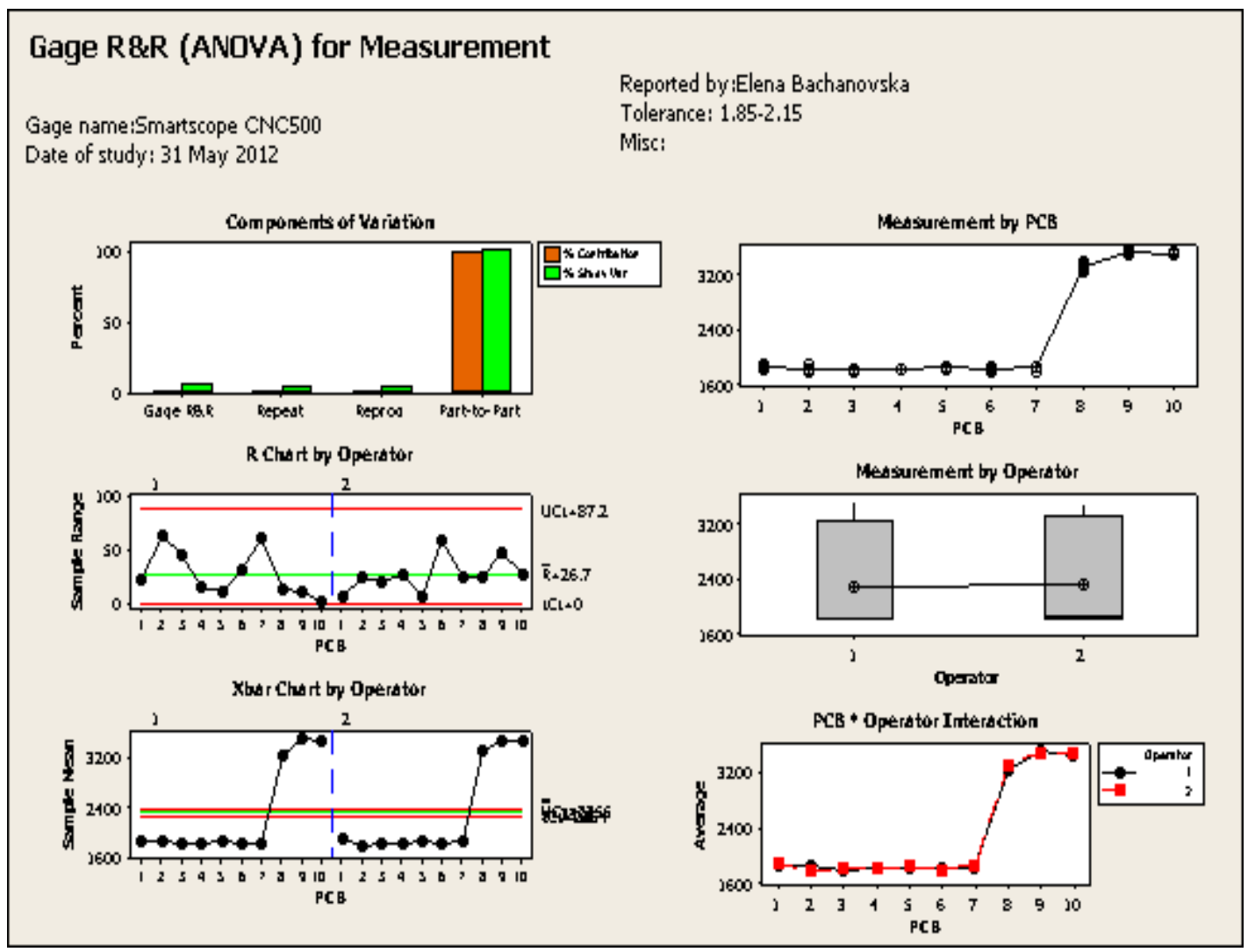

Fig. 10. Grafical table for validation of the measurement system 
For the appropriate data obtained in the measurements, it can be decided that the measurement of the PCU samples used in the process can be performed by $\mathrm{x}$-axis and $\mathrm{y}$-axis measurements to cover all directions of depanelization. This is shown in Figure 11.

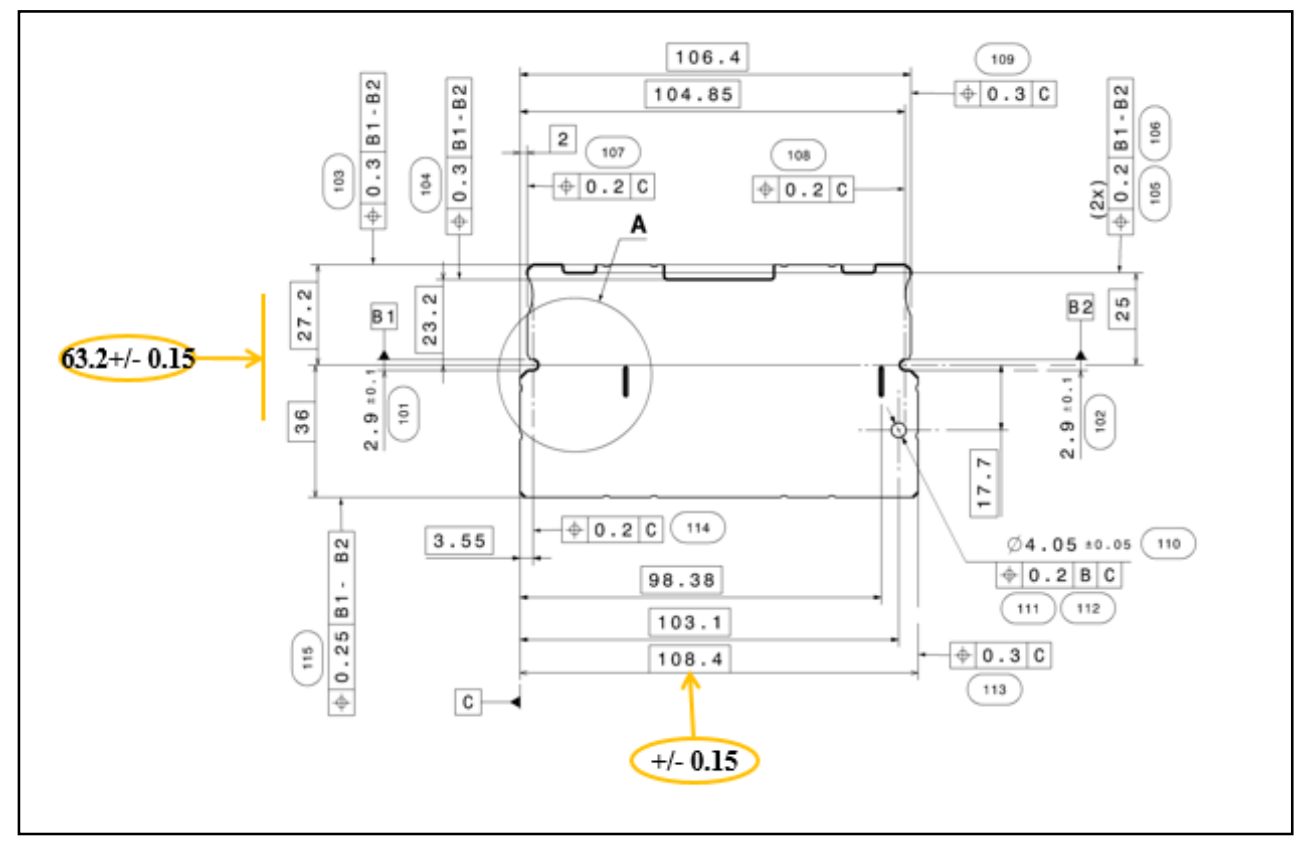

Fig. 11. Technical drawing of PCB with $x$ and $y$ dimensions with tolerances

\subsubsection{Normality tests, control diagram and} capability tests for the process by $x$-axis and $y$-axis

By measuring the dimensions of 30 printed electronic circuits along the $x$-axis and the $y$-axis, the normality test, the control diagram and the capability test were made. All tests are made at panel level.

The normality test given in Figure 12 shows that the process is not normal, $p<0.005$, for the $x$ axis, and the process is normal, $p=0.184$, for the $y$ axis.

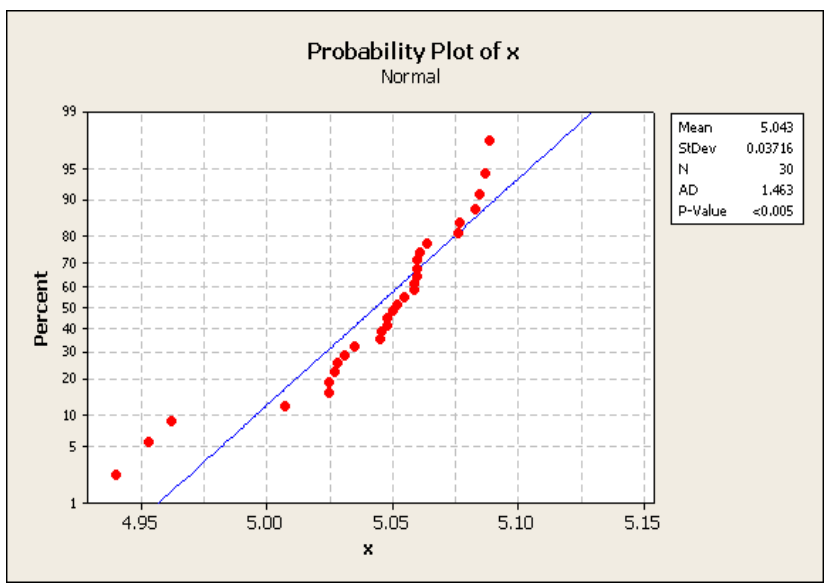

The control diagram given in figure 13 shows that the process is stable, in fact, none of the groups of printed electronic circuits (with a group of two circuits) does not go beyond the $x$-axis and $y$-axis control limits. In particular, only one group is at the $x$-axis limit value.

Capability test of the process given in Figure 14 shows that the process is not capable, $C_{p k}=P_{p k}$ (because the process is not normal) $=1$ for the $x$ axis and the process is not capable, i.e. $C_{p k}=0.97$ for the $y$-axis .

Fig. 12. Normality test for $x$-axis and $y$-axis 

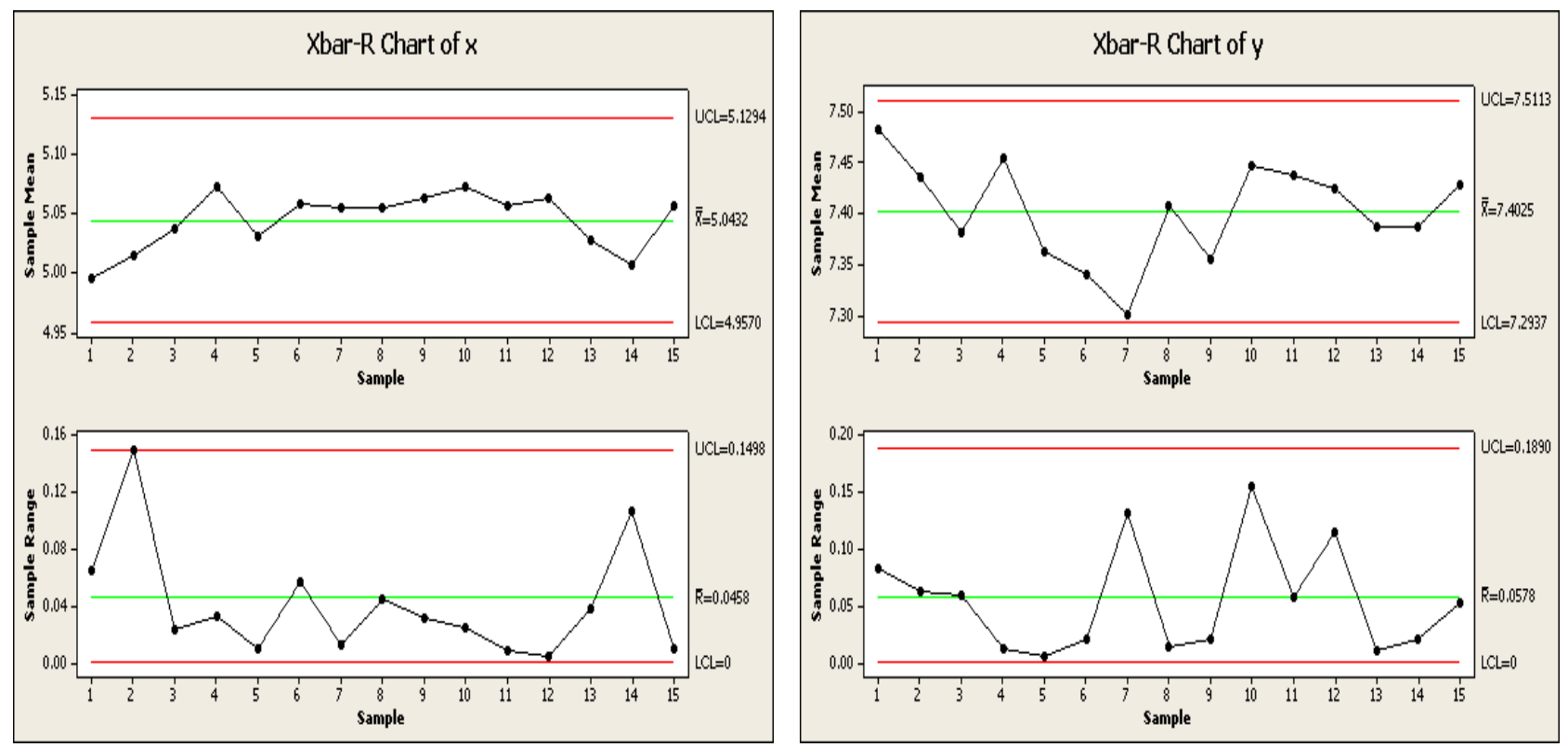

Fig. 13. Control diagram for $x$-axis and $y$-axis
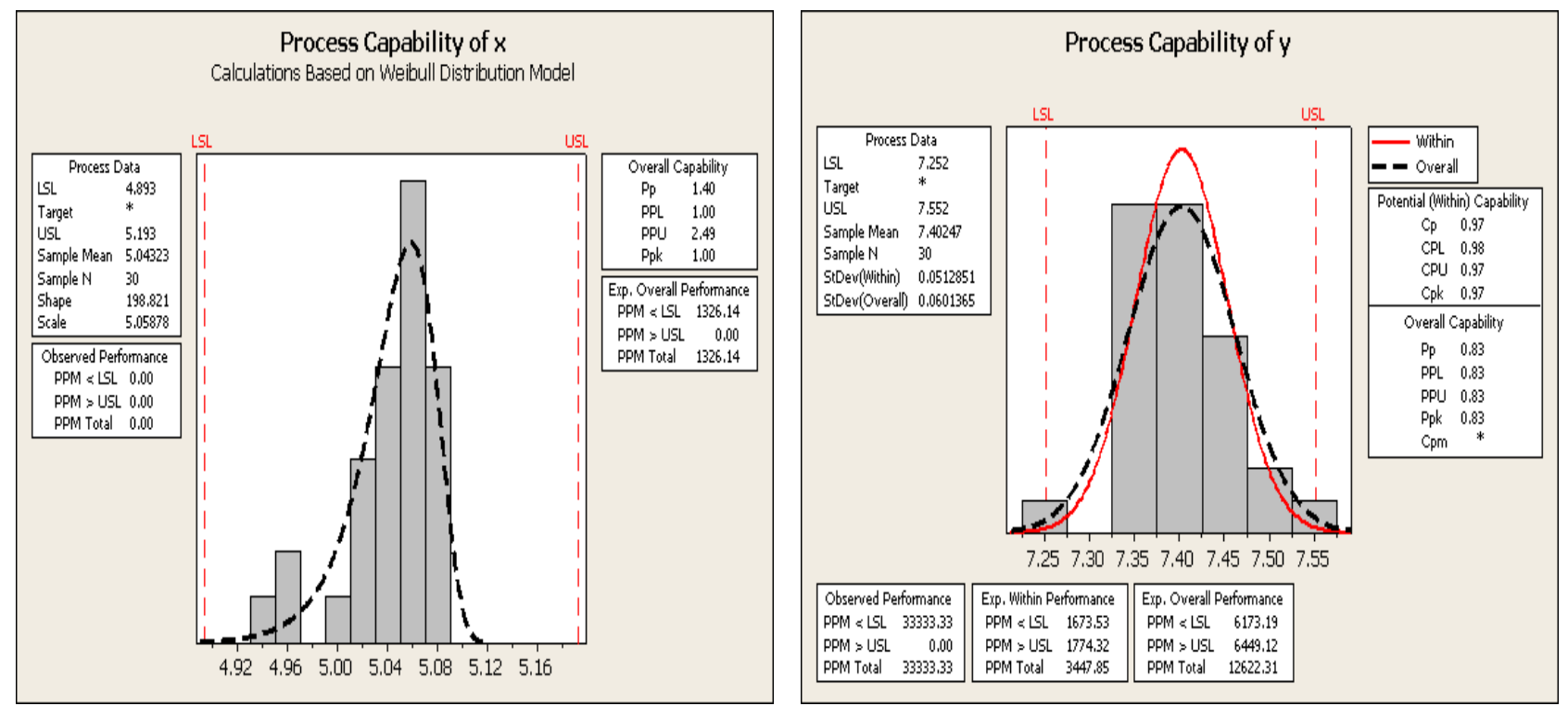

Fig. 14. Capability test for the process for $x$-axis and $y$-axis

With analyzing panel level information received does not provide a complete picture of the process, so 6 Sigma team concludes that it is necessary to analyze the printed circuit board level with the possibility to get more detailed information about the process of depaneling.

After the conducted analysis it was concluded that the measurements will have to be divided individually for each printed circuit board.

On the basis of the obtained observations, control diagrams for all printed electronic circuits are made, starting from the first to the sixth printed circuit board respectively, according to the $x$-axis and the $y$-axis.
With the detailed control diagrams made in $x$ axis and $y$-axis, each printed circuit board individually shows that the process is not stable in $\mathrm{x}$-axis for the printed circuit boards PCB 3, PCB 5 and PCB 6 , while along the $y$-axis for all six printed circuit boards on the panel (Figure 15).

With this kind of analysis and result 6 Sigma project can not continue, until the variation in the depanelization is eliminated.

\subsubsection{Stabilizing the process and repeated tests for the normality of the process}

The nature of the 6 Sigma methodology requires a stable process before starting the analysis 
and the process of improvement. The process should produce stable-predictable, more precisely defective products to appear consistently.

The 6 Sigma team is focused on analyzing the process and finding the cause of instability and variation in the process. After the analysis of the process, it was concluded that there was too much vibration of the panel on the support, which is placed along the $y$-axis of the milling machine. A solution is proposed that could reduce vibration by increasing the diameter of the supporting pins of the support on the dimensions $\Phi 3.9 \mathrm{~mm}$ and $\Phi 2.85 \mathrm{~mm}$. With this change in the support, it is expected that the panel will occupy a more secure position, with less vibrations during depanelization, and thus reduce the variation between the cuts. New pins were made and placed on the support for the panel of the machine for depanelizing. This is shown in Figure 16.


Fig. 15. Control diagrams for $x$-axis and $y$-axis (PCB1)

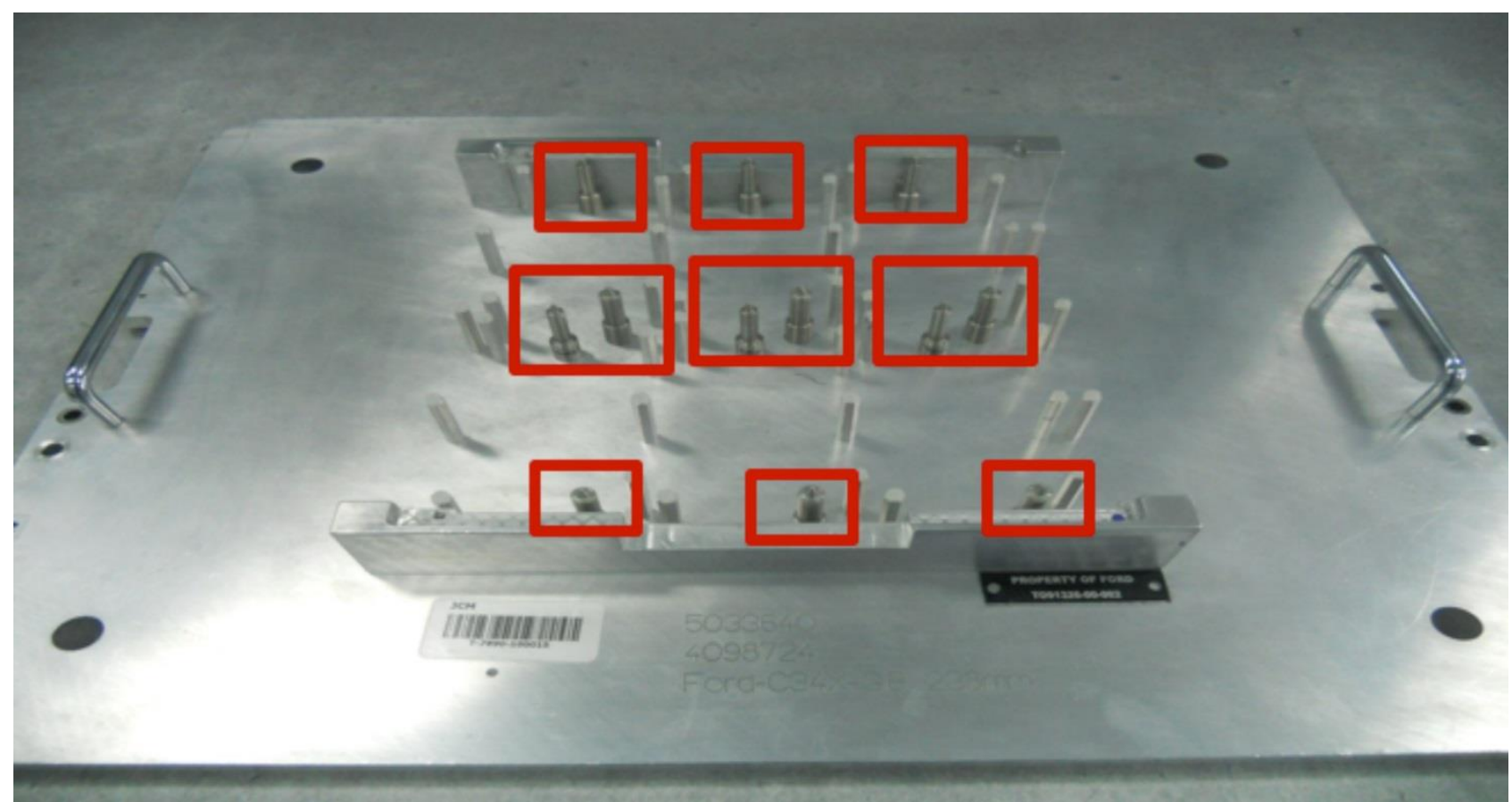

Fig. 16. Machine support for depanelization with marked changed pins 
After the change made to the pins, it is necessary to depanelized the new panels in a total of 30 printed circuit boards. For them, control diagrams are made to confirm whether there is a reduction in the variation in the process. In doing so, a re-analysis of the control diagrams is performed for all printed circuit boards respectively in the $x$-axis and in the $y$-axis.

With the detailed control diagrams made in the $x$-axis and in the $y$-axis for each printed circuit board respectively, it is shown that the process is stable in $x$-axis and in the $y$-axis for all the printed electronic circuits on the panel.

With this obtained result, the 6 Sigma project can proceed further in implementing the steps of the 6 Sigma methodology.

\subsubsection{Capability tests for the process for $x$-axis and $y$-axis}

Next is the elaboration of the tests for the ability of the $x$-axis and $y$-axis depanelization process for all six panel positions individually for the printed circuitry from PCB 1 to PCB 6. The capability of the process and the corresponding coefficients are given summarized in Table 1, whereby it can be verified that the process is not capable of proper depanelization of any position from the existing six on the panel, both in the $x$-axis and the $y$ axis.

\section{Table 1}

$$
C_{p k} \text { results for capability for } P C B 1 \text { to } P C B 6
$$

\begin{tabular}{ccc}
\multicolumn{3}{c}{ for $x$-axis and } \\
\hline \hline Cpk & $x$ & $y$ \\
\hline 1 & 1.21 & 1.89 \\
2 & 0.22 & 2.02 \\
3 & 1.70 & 2.10 \\
4 & 0.09 & 1.86 \\
5 & 1.40 & -0.77 \\
6 & 0.23 & -0.16 \\
\hline \hline
\end{tabular}

Accordingly, it can be concluded that the process of depaneling is an appropriate candidate for further analysis and improvement in order to enable it to produce the consistently required standards.

\subsection{Analyze phase}

Analyze phase is the most comprehensive phase that requires critical thinking and great dedication. At this stage 6 Sigma team must work as an individual with a common goal and devote sufficient time to the 6 Sigma project whenever necessary.

In the analyze phase, in the implementation of the appropriate required experiments, such as the DOE, there may be defective products, so in no case 6 Sigma team should not start the 6 Sigma project without the presence of a process expert. Also, it is necessary that all affected competent individuals are informed that on the process there is ongoing 6 Sigma project for smooth analysis and improvement.

The first step that 6 Sigma team does at this stage is analyzing with the brainstorming and using the diagram fish bone. Figure 17 shows the fish bone diagram for the depanelization process, analyzing the four elements of the process: people, machine, materials and methods.

For each of these elements the 6 Sigma team sets out the reasons that are probable possibilities to be the reason for the variation and malfunctioning of the panel.

By using the analysis WHY-WHY part of the possible reasons for variation divided by categories is rejected.

By eliminating some of the potential causes of malfunctioning and producing defective printed electronic circuits, there are still three potential causes (X1, X2 and X3) that need to be further analyzed.

\subsection{Improve phase}

From the analyze phase using DOE and hypothesis tests it has been determined that all three analyzed factors have an impact on the process of depanelization, and that factor B: speed of depanelization on the very process of depanelization in the $x$-axis and along the $y$-axis; and the factors A: $z$ axis; and $\mathrm{C}$ : fixation on the standard deviance.

All three factors need to be set at a minimum level to obtain the most accurate and stable process of depanelizing.

By setting the factors to a minimum level, seventeen (17) panels were depanelized to confirm the reduction in standard deviation. In this case, an analysis of all positions in the $x$-axis and along the $y$ axis was performed on all six positions of the PCB on the panel. With the results obtained, it can be concluded that by adjusting all three factors to a minimum level, a process of depanelization is obtained with a significantly lower standard deviation 
for all 6 (six) PCP positions in the panel and it is decided that this set of factors should be introduced into the production control plan, in order to start batch production with the changed factors.



Fig. 17. Fis-hbone diagram for depanelization process

\subsection{Control phase}

The control phase takes place in a test period of one month, as follows: on a daily basis the quality department notice a fall in the defectively depenetrated PCU and on a weekly basis if the client does not return the PCU with a defect of depanelization. At this stage, it is crucial to monitor the process on a daily basis in order to detect all the variations, and with slightest problem occurs the factors and improvement will be compromised and the process part will be restored to a dead end.
Internally by the team it is necessary to take 3 (three) randomly selected PCUs on a daily basis and take measurements within a month.

With the daily results obtained during the control month, backward tests of capability and control diagrams were performed. The results are shown in Figure 18 in the $x$-axis and on the $y$-axis, corresponding to all 6 (six) positions of the PCB on the panel.


Fig. 18. Capability tests for all six positions for $x$-axis and $y$-axis for PCB1 
An increased process capability for all 6 (six) positions is seen, as shown in Table 2 .

Table 2

$C_{p \kappa}$ capability results for $P C B 1$ to $P C B 6$ for $x$-axis and $y$-axis

\begin{tabular}{ccc}
\hline \hline Cpk & $x$-axis & $y$-axis \\
\hline 1 & 2.52 & 3.16 \\
2 & 1.58 & 2.80 \\
3 & 1.22 & 2.19 \\
4 & 1.39 & 2.64 \\
5 & 1.44 & 0.66 \\
6 & 1.39 & 0.67 \\
\hline \hline
\end{tabular}
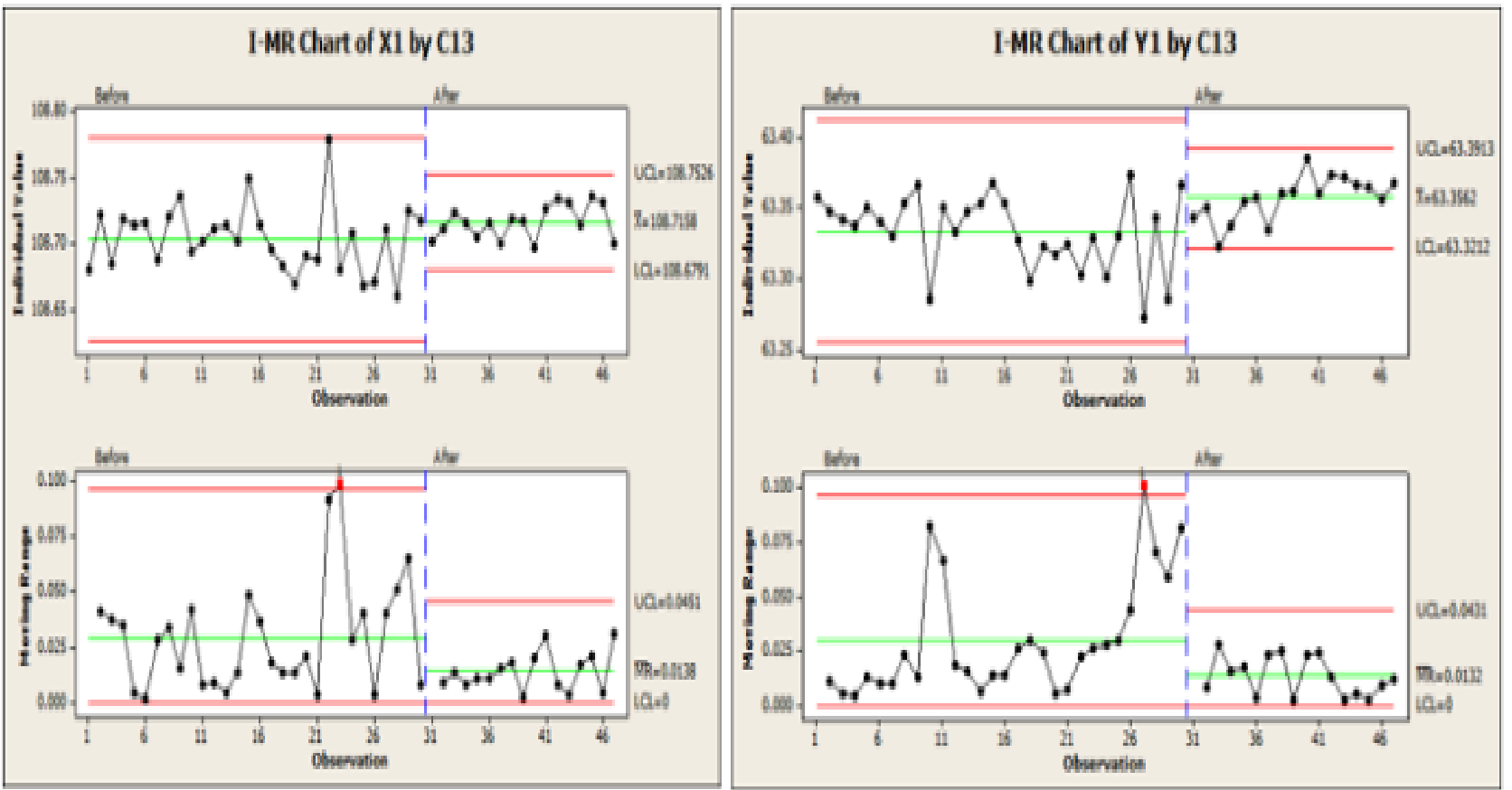

Fig. 19. Control diagrams before-after for PCB 1 to PCB6 for $x$-axis and $y$-axis

Table 3

Standard deviation values before-after for PCB1 to PCB6

\begin{tabular}{cccccc}
\hline \hline \multicolumn{5}{c}{ Standard deviation values } & \multicolumn{2}{c}{ before-afte } \\
\cline { 5 - 7 } & Before & After & & Before & After \\
\hline $\mathrm{X} 1$ & 0.26 & 0.13 & $\mathrm{Y} 1$ & 0.26 & 0.16 \\
$\mathrm{X} 2$ & 0.53 & 0.21 & $\mathrm{Y} 2$ & 0.25 & 0.14 \\
$\mathrm{X} 3$ & 0.25 & 0.17 & $\mathrm{Y} 3$ & 0.22 & 0.12 \\
$\mathrm{X} 4$ & 0.37 & 0.17 & $\mathrm{Y} 4$ & 0.31 & 0.13 \\
$\mathrm{X} 5$ & 0.35 & 0.19 & $\mathrm{Y} 5$ & 0.24 & 0.23 \\
$\mathrm{X} 6$ & 0.32 & 0.22 & $\mathrm{Y} 6$ & 0.27 & 0.24 \\
\hline \hline
\end{tabular}

\subsection{Analyze and improvement}

By analyzing the control diagrams given in Figure 19 and in Table 3, it is found that the process is with narrower boundary values and with reduced standard deviation.

In none of the positions there is no unit that comes out of the control boundaries. With these analyses 6 Sigma project is closed and is proclaimed for successfully implemented 6 Sigma improvement project. 
and variations to become more competitive on the market and to establish a suitably acceptable relationship with its customers by delivering products and/or services that have the required quality and timely delivered or performed.

The practical example demonstrates the ability of the 6 Sigma methodology to stabilize and improve the production process. It is delicate enough to be enhanced during the day-to-day adjustment of parameters or be enhanced with tools that contain a lower level of statistical analysis.

Using the DMAIC model in the 6 Sigma methodology helped the team in improvement of the process of depanelization through stabilization of the process was carried out, narrower limit values were obtained at all PCB positions and a significant decrease in the standard deviation by up to $50 \%$ for part of the positions.

The very improvement of the product and the machine for the depanelization in the production capacity has been analyzed and replicated as a good practice of all the same machines for the entire range of products.

The fixing and placement of the $z$-axis of the tool is implemented in the same way for all products and machines while the speed of depaneling is adjusted depending on the material of the product, its defective category and production capacity. This shows that the 6 Sigma methodology is powerful enough that results obtained from one improvement can be replicated and standardized on processes that are of the same nature as the one subjected to analysis.

\section{REFERENCES}

[1] McCarty, T., Daniels, L., Bremer, M., Gupta, P.: The Six Sigma Black Belt Handbook, McGraw-Hill, 2004.

[2] Minitab софйверски йакей, верзија 17, Minitab Inc, USA.

[3] Papazoska, E.: Application of the 6 Sigma Method to Improving the Capability of the Production Process, Master thesis, UKIM, Faculty of Mechanical Engineering, Скопје, June 2019 (in Macedonian).

[4] Sheehy, P., Navarro, D., Silvers, R., Keyes, V., Dixon, D., Picard, D.: The Black Belt Memory Jogger: A Pocket Guide for Six Sigma Success, Goal/QPC, January 2002.

[5] Wiklund, H., Edgeman, R.: Six sigma Seen as a Methodology for Total Quality Management, Measuring Bussiness Excelence, March 2001.

[6] Henderson, R. G.: Šest Sigma Quality Improvement with Minitab, A John Wiley \& Sons, Ltd Publications, 2011.

[7] Lazibat, T., Baković, T.: Šest sigma sustav za upravljanje kvalitetom, Znanstveni časopis za promicanje kulture kvalitete i poslovne izvrsnosti, Vol. 1, No. 1, pp. 55-66 (2007).

[8] ISO 13053-1: Quantitative methods in process improvement - Six Sigma, Part 1: DMAIC methodology, 2011.

[9] ISO 13053-2: Quantitative methods in process improvement - Six Sigma, Part 2: Tools and techniques, 2011.

[10] ISO 18404: Quantitative methods in process improvement - Six Sigma. Competencies for key personnel and their organizations in relation to Six Sigma and lean implementation, 2015.

[11] http://www.asq.org/topics/sixsigma.htm (accessed on 15. 01. 2019).

[12] Milosavljević, P.: Six Sigma Metoda, Mašinski fakultet u Nišu, Srbija, Oktober 2016.

[13] Wilson, D., Wiltsie, P.: PMPA - Lean Six Sigma tools and methods, 2005 (https://www.pmpa.org/docs/defaultsource /technical-conference/09-today\%27s-quality-lean. Pdf?sf $\underline{v r s n}=0$ ) (accessed on 15. 01. 2019).

[14] Lazić, M.: Six Sigma - Metodology for quality improvement, Quality Festival, Kragujevac, Serbia, May 2011. 